B I O S C I E N C E

J O U R N A

\title{
CHEMICAL MANAGEMENT OF Cyperus rotundus L. AND OTHER WEEDS AT SUGARCANE IN PSS SYSTEM
} OTHER WEEDS AT SUGARCANE INPSS SYSTEM

\author{
Ana Ligia GIRALDELI ${ }^{1,2}$ (D) , André Felipe Moreira SILVA ${ }^{3}$ (D), Luisa Carolina BACCIN² iD, \\ Lucas da Silva ARAúJO2 (iD, Gustavo Soares da SILVA² (iD), \\ Ana Carolina Viviani PAGENOTTO4 ${ }^{\text {(D) }}$, Ricardo VICTORIA FILHO ${ }^{5}$ (D)
}

1 Department of Agronomy, State University of Londrina, Londrina, Paraná, Brazil.
2 Postgraduate Program in Crop Science, University of São Paulo, Luiz de Queiroz College of Agriculture, Piracicaba, São Paulo, Brazil.
${ }^{3}$ Crop Science Pesquisa e Consultoria Agronômica, Palotina, Paraná, Brazil.
${ }^{4}$ Graduation in Agronomic Engineering, University of São Paulo, Luiz de Queiroz College of Agriculture, Piracicaba, São Paulo, Brazil.
${ }^{5}$ Department of Crop Science, University of São Paulo, Luiz de Queiroz College of Agriculture, Piracicaba, São Paulo, Brazil.

Corresponding author:

Ana Ligia Giraldeli

Email: analigia_giraldeli@hotmail.com

How to cite: GIRALDELI, A.L., et al. Chemical management of Cyperus rotundus L. and other weeds at sugarcane in PSS system. Bioscience Journal. 2021, 37, e37056. https://doi.org/10.14393/BJ-v37n0a2021-51527

\begin{abstract}
Among the main weeds with difficult to control in the sugarcane fields can be cited purple nutsedge (Cyperus rotundus L.). This specie was observed in the seed bank in sugarcane fields harvested with or without burning. The objective of this study was to evaluate the efficacy of herbicides in pre-sprouted seedlings (PSS) of sugarcane in the control of $C$. rotundus and other weeds. The work was carried out in the field, in a randomized complete block design, and four replications. The treatments corresponded to the herbicides applied in pre-planting: sulfentrazone (800 g a.i. ha $\left.{ }^{-1}\right)$, diclosulam (193.17 g a.i. ha-1), imazapic (133 g a.i. ha$\left.{ }^{1}\right)$ and imazapyr (500 g a.e. ha- ${ }^{-1}$ ); post-planting: halosulfuron (112.5 g a.i. ha ${ }^{-1}$ ), ethoxysulfuron (135 g a.i. ha1), MSMA (1,975 g a.i. ha-1) and 2,4-D (1,340 g a.e. ha-1 ${ }^{-1}$; besides a control treatment weeding and another without weeding. The symptoms of injury on sugarcane plants, percentage of weed control, variables related to agronomic performance of sugarcane, and yield were evaluated. The herbicides diclosulam, imazapic, and imazapyr caused serious damage to the crop. The halosulfuron, ethoxysulfuron, MSMA, and 2,4-D did not cause symptoms of injury to sugarcane, however, the treatments had a reduced yield due to the low weed control. The sulfentrazone treatment obtained the second highest yield but with effective weed control (>70\%) up to 45 days after planting. The best controls were obtained with pre-planting treatments; however, herbicide positioning studies should be performed in relation to PSS.
\end{abstract}

Keywords: Control. Herbicides. Post-planting. Pre-planting. Saccharum spp.

\section{Introduction}

Among the main weeds with difficult to control in the sugarcane fields can be cited purple nutsedge (Cyperus rotundus L.). This specie was observed in the seed bank in sugarcane fields harvested with or without burning (Ferreira et al. 2013), with quantities of up to $15 \mathrm{t} \mathrm{ha}^{-1}$ of straw (Ferreira et al. 2010), considered the main weed among the 15 species found, presenting high accumulated Relative Importance (IR\%) of 1,299 in green cane (Kuva et al. 2007). Regarding the influence of Cyperus spp. on sugarcane, this weed can reduce until $45.2 \%$ of the yield of sugarcane (Durigan et al. 2005). Also, the level of interference of $C$. rotundus can also vary according to the sugarcane cultivar, at the pre-sprouted seedling (PSS) system (Giraldeli et al. 2018). Among the weeds belonging to the Cyperaceae family can be cited $C$. difformis L., $C$. 
esculentus L., C. iria L., C. odoratus L., and C. rotundus. These species have characteristics in common, such as triangular stem and can be annual or perennial, herbaceous, and erect. Depending on the species reproduction occurs via seeds as in the case of $C$. difformis, $C$. iria e $C$. odoratus. For $C$. esculentus e $C$. rotundus reproduction also occurs via tubers, being very expressive for the second species (Alves et al. 2009; Lorenzi 2014).

For $C$. rotundus, reproduction via tubers makes it difficult to control, especially the chemical, because the herbicides need to translocate in the plant and reach sufficiently to the organs of vegetative propagation (Brecke et al. 2005). In this context, some products used in sugarcane may help control, such as diclosulam, imazapic, imazapyr, sulfentrazone, MSMA, 2,4-D, halosulfuron, glyphosate and ethoxysulfuron, applied at pre, post or late post-emergence, as recommended (Rodrigues and Almeida 2018).

Herbicides sulfentrazone ( $800 \mathrm{~g}$ a.i. ha $\left.{ }^{-1}\right)$, imazapic $\left(147 \mathrm{~g}\right.$ a.i. ha $\left.{ }^{-1}\right)$ and halosulfuron $\left(112,5 \mathrm{~g}\right.$ a.i. ha- $\left.{ }^{-1}\right)$ reduced the number and weight of viable tubers and increased the number of dead tubers of $C$. rotundus, compared to control without application, highlighting sulfentrazone (Silva et al. 2014). However, further studies are needed to understand the chemical management of $C$. rotundus in PSS. It is noteworthy that in areas where PSSs are planted for the purpose of multiplication for commercial areas there is no straw, which favors weeds of smaller and photoblastic positive seeds, such as Poaceae family species, which hinders the management with herbicides of broad spectrum (Silva et al. 2018). Thus, if chemical management may differ in the PSS system, this study aimed to evaluate the efficacy of herbicides for the control of $C$. rotundus and other weeds in pre-sprouted sugarcane seedlings.

\section{Material and Methods}

The experiment was carried out in an experimental area in Piracicaba, state of São Paulo, Brazil $\left(22^{\circ} 42^{\prime} 47.8^{\prime \prime} \mathrm{S} 47^{\circ} 37^{\prime} 14.6^{\prime \prime} \mathrm{W}\right.$, altitude $\left.547 \mathrm{~m}\right)$. The climate of the region, according to Köeppen classification is Cwa type, relatively dry in winter, with rain in summer. Figure 1 shows the rainfall and temperature data during the experiment months.

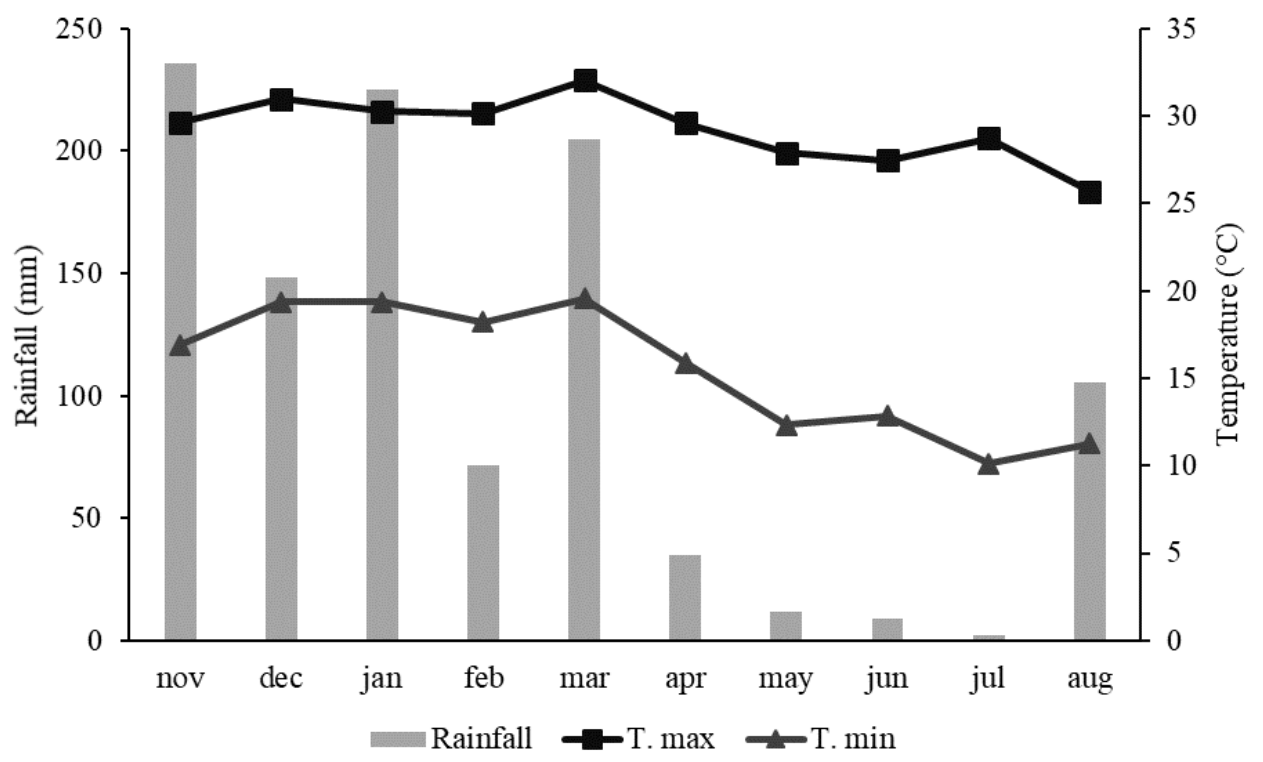

Figure 1. Rainfall $(\mathrm{mm})$, mean maximum and minimum temperature $\left({ }^{\circ} \mathrm{C}\right)$ while conducting the experiment. Piracicaba, SP, Brazil, 2017/18.

The results of the chemical analysis of the soil are presented in Table 1, being classified as medium texture ( $76.3 \%$ sand, $6.2 \%$ silt, and $17.5 \%$ clay). Before the installation of the experiment, a phytosociological survey of the area (November 2017) by sampling using $0.5 \mathrm{~m}$ side cast iron squares with an internal area of $0.25 \mathrm{~m}^{2}$, which were launched 15 times at random. The sampled plants were counted, identified, and stored in properly identified paper bags and placed to dry in a forced air circulation oven at $65^{\circ} \mathrm{C}$ for $48 \mathrm{~h}$ to obtain the dry mass. With the sampled data we performed the descriptive analysis of weeds through 
phytosociological parameters represented by the IR\% and IVI of the species present in the experimental area (Mueller-Dombois and Ellenberg 1974). These parameters will be shown in the results.

Table 1. Results of soil chemical analysis of the experimental area. Piracicaba, SP, Brazil, 2017/18

\begin{tabular}{cccccccccccc}
\hline $\mathrm{P}$ (Resin) & $\mathrm{M} . \mathrm{O}$. & $\mathrm{pH}$ & $\mathrm{K}$ & $\mathrm{Ca}$ & $\mathrm{Mg}$ & $\mathrm{Al}$ & $\mathrm{H}+\mathrm{Al}$ & $\mathrm{SB}$ & $\mathrm{CEC}$ & $\mathrm{V}$ & $\mathrm{m}$ \\
\hline $\mathrm{mg} \mathrm{dm}^{-3}$ & $\mathrm{~g} \mathrm{dm}^{-3}$ & $\mathrm{CaCl}_{2}$ & & & & $\mathrm{mmol}_{\mathrm{c}} \mathrm{dm}^{-3}$ & & & $\%$ \\
\hline 11 & 17 & 5.5 & 4.6 & 26 & 9 & $<2$ & 12 & 36.1 & 48.1 & 75 & 3 \\
\hline
\end{tabular}

The experiment was installed in an area previously cultivated with soybean. Mechanical cultivation was carried out, fertilization with $320 \mathrm{~kg} \mathrm{ha}^{-1}$ of 08-24-20 (N-P-K) in the planting furrow and application of $400 \mathrm{~g}$ a.i. ha ${ }^{-1}$ of fipronil (Regent $800 \mathrm{WG}$, Basf); three weeks after planting, $10.5 \mathrm{~g}^{\oplus}$ a.i. ha ${ }^{-1}$ of $^{\circ}$ chlorantraniliprole (Altacor ${ }^{\circ}$, WG, DuPont) was applied. The seedlings of cultivar IACSP95-5000 were planted on December 12, 2017, with planting lines spaced $1.5 \mathrm{~m}$ and $0.65 \mathrm{~m}$ between seedlings in the planting line. The plots consisted of five lines of six meters in length $\left(36 \mathrm{~m}^{2}\right)$, totaling 45 plants per plot (nine plants per line). For the evaluations, it was considered the useful area of the plots, the three central lines, excluding one meter at the beginning and end of the plot. After planting, the area was irrigated (approximately 20 $\mathrm{mm})$.

The experimental design was randomized blocks with 10 treatments (Table 2) and four replications. PRE-planting herbicides were applied one day before sugarcane planting, the post-planting herbicides were applied when $C$. rotundus plants were in full vegetative development ( 4 to 5 leaves) at 30 days after planting (DAP). All herbicides recommended for control of $C$. rotundus in sugarcane were used, even knowing the possible damage to the crop in this application modality, as is the case of imazapyr (Rodrigues and Almeida 2018).

Table 2. Treatments used for the control of C. rotundus. Piracicaba, SP, Brazil, 2017/18.

\begin{tabular}{lllll}
\hline Treatments & Commercial product & Rate $^{1}$ & Rate $^{2}$ & Time $^{3}$ \\
\hline 1. control with weeding & - & - & - & - \\
2. control without weeding & - & - & - & - \\
3. sulfentrazone & Boral $^{\oplus} 500 \mathrm{SC}$ & $1.6 \mathrm{~L}$ & 800 & PRE \\
4. diclosulam & Coact $^{\oplus}$ & $230 \mathrm{~g}$ & 193.17 & $\mathrm{PRE}$ \\
5. imazapic & Plateau $^{\oplus}$ & $190 \mathrm{~g}$ & 133 & $\mathrm{PRE}$ \\
6. imazapyr & Contain $^{\oplus}$ & $2.0 \mathrm{~L}$ & 500 & PRE \\
7. halosulfuron & Sempra $^{\oplus}$ & $150 \mathrm{~g}$ & 112.5 & POST \\
8. ethoxysulfuron & Gladium $^{\oplus}$ & $225 \mathrm{~g}$ & 135 & POST \\
9. MSMA & Volcane $^{\oplus}$ & $2.5 \mathrm{~L}$ & 1,975 & POST \\
10. 2,4-D & DMA $^{\oplus} 806 \mathrm{BR}$ & $2.0 \mathrm{~L}$ & 1,340 & POST \\
\hline
\end{tabular}

${ }^{1}$ Rates of commercial products ha $^{-1}{ }^{2}{ }^{2}$ Rates at $\mathrm{g}$ a.i. $\mathrm{ha}^{-1}$, and at $\mathrm{g}$ a.e. ha- ${ }^{-1}$ for 2,4-D and imazapyr; ${ }^{3}$ Herbicide application time: PRE-planting (one day before planting) and POST-planting (30 DAP).

The spraying was carried out via $\mathrm{CO}_{2}$ pressurized sprayer, equipped with a bar with four spray nozzles, and flat spray fan type (XR110.02), at a constant pressure of $2.1 \mathrm{kgf} \mathrm{cm}^{-2}$, providing a spray volume of $200 \mathrm{~L}$ $\mathrm{ha}^{-1}$, and velocity of $1 \mathrm{~m} \mathrm{~s}^{-1}$, with the tips positioned at a height of $50 \mathrm{~cm}$ from the target. At the time of PRE applications, the environmental conditions were $26.2^{\circ} \mathrm{C}, 2.7 \mathrm{~m} \mathrm{~s}^{-1}$, and $63 \%$ relative air humidity. In POST applications, the environmental conditions were $25^{\circ} \mathrm{C}, 1.5 \mathrm{~m} \mathrm{~s}^{-1}$, and $86 \%$ relative air humidity. For POST herbicide applications, the non-ionic adhesive spreader $\left(\mathrm{Agral}^{\circledR}\right)$ was used for the halosulfuron, MSMA, and 2,4-D, at rates of $0.5 \% \mathrm{v} / \mathrm{v}, 100 \mathrm{~mL}$ per $100 \mathrm{~L}$ of water and $0,3 \% \mathrm{v} / \mathrm{v}$, respectively.

The PSSs were evaluated for symptoms of injury through visual evaluations, in which percentages were assigned to each experimental unit ( 0 for no injuries, up to $100 \%$ for plant death), considering in this case symptoms significantly visible in the plants, according to their development (European Weed Research Council [EWRC] 1964). These evaluations were performed at 30, 45, 60, 75, and 90 DAP. Weed control was evaluated by visual scores ranging from 0 to $100 \%$, where zero represents no control and $100 \%$ no weed 
(Velini et al. 1995). These evaluations were performed at 15, 30, 45, 60, 75, and 90 DAP, the first two only for pre-planting treatments. At $90 \mathrm{DAP}$, weeds were collected to determine dry mass. In these samples were used cast iron squares with $0.5 \mathrm{~m}$ side and internal area of $0.25 \mathrm{~m}^{2}$, which were randomly thrown twice in the useful area of the plots. The sampled plants were cut close to the ground, stored in properly identified paper bags, and placed to dry in a forced circulation oven at $65^{\circ} \mathrm{C}$ for $48 \mathrm{~h}$ to determine the dry mass.

Height, diameter, and the number of tillers were evaluated at 60, 90, and 120 DAP. For this, five plants per plot were measured in each evaluation regarding the variables: height of the soil plant to the last expanded leaf, made with millimeter wooden ruler and results expressed in centimeters; stem diameter five $\mathrm{cm}$ high from the ground, made with digital calipers and results expressed in millimeters; and the number of tillers. At 240 DAP, plant height and diameter were also performed. Sugarcane yield was estimated for each treatment at 240 DAP. For this, we counted the number of stalks in six meters, and the weighing of ten stalks of each plot, which were cut at ground level, cleaned, and weighed on a scale to obtain the mass. The data obtained were extrapolated to tons of sugarcane per hectare.

Data on injury symptoms and weed control were analyzed descriptively. For the other variables, the data were submitted to analysis of variance and F-test $(p<0.05)$, and when significant, the means were compared by Scott-Knott test $(p<0.05)$ (Pimentel-Gomes and Garcia 2002). The Sivar 5.6 program was used for the analysis (Ferreira 2011).

\section{Results}

The phytosociological survey of the area showed the presence of 12 weed species belonging to six families. Of these, $58.33 \%$ are monocotyledonous and $41.66 \%$ eudicotyledonous. The weeds with higher IR\% were: C. rotundus (32.35\%), Alternanthera tenella Colla (22.51\%), Digitaria ciliaris (Retz.) Koeler (15,56\%) and Portulaca oleraceae L. (7.45\%). The IVI and IR\% are represented in Figure 2. The weeds that occurred in the area and their respective families were: Amaranthaceae: Amaranthus viridis L., A. tenella; Asteraceae: Bidens subalternans DC., Emilia fosbergii Nicolson; Commelinaceae: Commelina benghalensis L.; Cyperaceae: C. rotundus; Poaceae: Cenchrus echinatus L., D. ciliaris, Eleusine indica (L.) Gaertn, Panicum maximum Jacq., Urochloa plantaginea (Link) R.D. Webster; Portulacaceae: P. oleraceae.

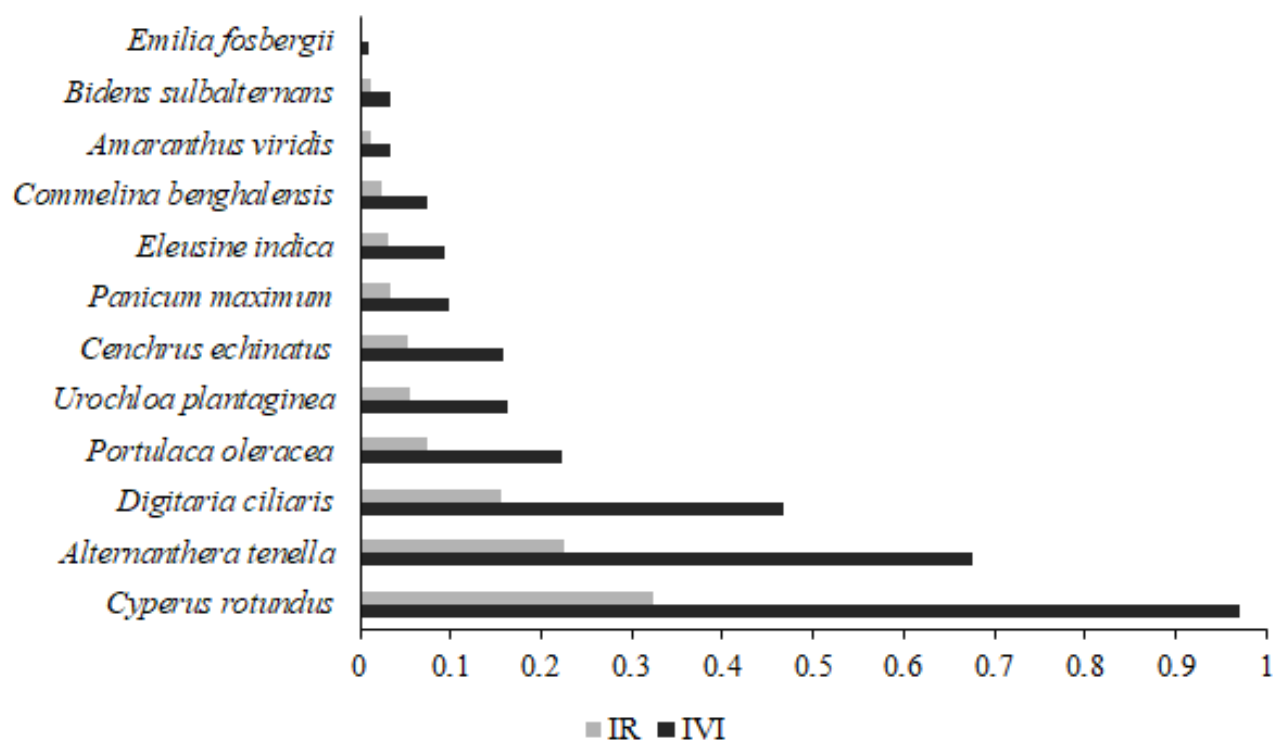

Figure 2. Relative Importance (IR\%) and Importance Value Index (IVI) of weed species present in the experimental area. Piracicaba, SP, Brazil, 2017/18 season.

Symptoms of injury were high for pre-planting herbicides at 30 DAP. Diclosulam provided symptoms of $33.8 \%$, visually characterized by chlorosis of the leaves of the crop. Already imazapic and sulfentrazone caused up to $37.5 \%$ of the injury, for the second herbicide reddish spots were observed in the leaf limb. Imazapyr was the most harmful to the crop, with $73.8 \%$ of symptoms of injury, with intense chlorotic spots 
on the leaves. The herbicide sulfentrazone caused symptoms of sugarcane injury up to 45 DAP, with a reduction to $20 \%$ in this evaluation, and to $0 \%$ from 60 DAP. For diclosulam, injuries were verified up to 90 DAP, with the highest value at 75 DAP (58.8\%). It was observed that the herbicide caused the growth and development of sugarcane plants to stop, which also occurred with the application of imazapic. Already imazapyr caused severe injuries since the 30 DAP. For post-planting herbicides (halosulfuron, ethoxysulfuron, MSMA, and 2,4-D) no symptoms of injury were observed in sugarcane plants in any of the evaluations performed (Table 3).

Table 3. Crop injury in pre-sprouted seedlings, cultivar IACSP95-5000, at 30, 45, 60, 75, and 90 DAP. Piracicaba, SP, Brazil, 2017/18.

\begin{tabular}{lccccccc}
\hline \multirow{2}{*}{ Treatments } & \multirow{2}{*}{ Rates $^{1}$} & \multirow{2}{*}{ Time $^{2}$} & \multicolumn{5}{c}{ Crop injury (\%) at DAP } \\
\cline { 5 - 8 } & & & 30 & 45 & 60 & 75 & 90 \\
\hline control with weeding & - & - & 0.0 & 0.0 & 0.0 & 0.0 & 0.0 \\
control without weeding & - & - & 0.0 & 0.0 & 0.0 & 0.0 & 0.0 \\
sulfentrazone & 800 & PRE & 37.5 & 20.0 & 0.0 & 0.0 & 0.0 \\
diclosulam & 193.17 & PRE & 33.8 & 46.3 & 51.3 & 58.8 & 48.8 \\
imazapic & 133 & PRE & 37.5 & 48.8 & 57.5 & 57.5 & 50.0 \\
imazapyr & 500 & PRE & 73.8 & 88.8 & 92.5 & 96.0 & 95.5 \\
halosulfuron & 112.5 & POST & - & 0.0 & 0.0 & 0.0 & 0.0 \\
ethoxysulfuron & 135 & POST & - & 0.0 & 0.0 & 0.0 & 0.0 \\
MSMA & 1,975 & POST & - & 0.0 & 0.0 & 0.0 & 0.0 \\
2,4-D & 1,340 & POST & - & 0.0 & 0.0 & 0.0 & 0.0 \\
\hline
\end{tabular}

DAP: days after planting; ${ }^{1}$ Rates at g a.i. ha- ${ }^{-1}$, and at g a.e. ha- ${ }^{-1}$ for 2,4-D and imazapyr; ${ }^{2}$ Herbicide application time: PRE-planting (one day before planting) and POST-planting (30 DAP).

Regarding weed control, pre-planting herbicides were generally the ones with the best results. Up to 45 DAP, all pre-planting herbicides provided "good" control (71-80\%). After this period only imazapyr provided control above $70 \%$, which resulted in a lower dry mass value at 90 DAP ( $41.88 \mathrm{~g})$. All herbicides reduced the percentage of control throughout the evaluations and the dry mass at 90 DAP. From 60 DAP, there was a reduction in control percentages for pre-planting herbicides. For the species $C$. rotundus it was verified that the herbicides imazapic, imazapyr, and diclosulam acted as preventing the emergence of the species and possibly the germination of the tubers. For sulfentrazone, it is observed that the weeds emerge with the herbicide symptoms, which evolve until the plant dies. The symptoms found were chlorotic spots on leaves with evolution to necrosis and consequent death. Post-planting herbicide control was not feasible as it did not result in efficient weed controls. The maximum control was obtained for halosulfuron and ethoxysulfuron at 90 DAP, with 23.8 (114.4 g) and 25\% (112.7 g), respectively. All treatments reduced the dry mass in relation to the control without weeding, however, they were not equal to the control with weeding (Table 4). 
Table 4. Control and dry mass of $C$. rotundus, and other weeds, in pre-sprouted seedlings, cultivar IACSP955000, at 15, 30, 45, 60, 75 and 90 DAP. Piracicaba, SP, Brazil, 2017/18.

\begin{tabular}{lccccccccc}
\hline \multirow{2}{*}{ Treatments } & \multirow{2}{*}{ Rates $^{1}$} & \multirow{2}{*}{ Time $^{2}$} & \multicolumn{7}{c}{ Control (\%) at DAP $^{*}$ Dry mass (g) } \\
\cline { 5 - 9 } control with weeding & - & - & 100.0 & 100.0 & 100.0 & 100.0 & 100.0 & 100.0 & $0.0^{\mathrm{a}}$ \\
control without weeding & - & - & 0.0 & 0.0 & 0.0 & 0.0 & 0.0 & 0.0 & $219.0^{\mathrm{f}}$ \\
sulfentrazone & 800 & PRE & 91.7 & 90.0 & 71.3 & 55.0 & 41.3 & 31.3 & $79.7^{\mathrm{c}}$ \\
diclosulam & 193.17 & PRE & 82.7 & 92.5 & 80.0 & 71.3 & 56.3 & 25.0 & $102.9^{\mathrm{d}}$ \\
imazapic & 133 & PRE & 80.0 & 87.5 & 73.8 & 62.5 & 57.5 & 35.0 & $50.2^{\mathrm{b}}$ \\
imazapyr & 500 & PRE & 83.3 & 87.0 & 83.8 & 82.5 & 73.8 & 57.5 & $41.9^{\mathrm{b}}$ \\
halosulfuron & 112.5 & POST & - & - & 0.0 & 3.3 & 11.3 & 23.8 & $114.4^{\mathrm{d}}$ \\
ethoxysulfuron & 135 & POST & - & - & 0.0 & 3.8 & 17.5 & 25.0 & $112.7^{\mathrm{d}}$ \\
MSMA & 1,975 & POST & - & - & 0.0 & 0.0 & 1.3 & 13.8 & $188.9^{\mathrm{e}}$ \\
2,4-D & 1,340 & POST & - & - & 0.0 & 10.0 & 8.8 & 20.0 & $148.4^{\mathrm{e}}$ \\
\hline & & & & & & & & Mean & 105.8 \\
& & & & & & & & CV (\%) & 9.0 \\
\end{tabular}

DAP: days after planting; ${ }^{1}$ Rates at g a.i. ha-1 , and at g a.e. ha-1 for 2,4-D and imazapyr; ${ }^{2}$ Herbicide application time: PRE-planting (one day before planting) and POST-planting (30 DAP).* Means followed by the same letter in the column do not differ by the Scott-Knott test $(p<0.05)$.

The highest sugarcane heights were obtained for treatments without weeding and post-planting herbicide application, probably due to the greater competition established in these plots, resulting from the low control provided, causing the search for luminosity. Sulfentrazone resulted in height equal to control (with weeding). For diclosulam, imazapic and imazapyr were the lowest heights. Concerning the stem diameter (60 DAP), the lowest values were verified for the herbicides diclosulam, imazapic and imazapyr compared to the control with weeding and without weeding. In this evaluation, the number of tillers was lower for all treatments compared to control (with weeding). Among the pre-planting herbicides, the largest number of tillers was in sulfentrazone treatments. The analysis of variance was significant at 90 DAP for the variables: height, diameter, and the number of tillers. The lowest heights and diameters were observed for diclosulam, imazapic, and imazapyr application, compared to weeding control, however, sulfentrazone did not differ from imazapic for the variable height. All herbicides and control (without weeding) reduced the number of tillers when compared to control (with weeding) (Table 5).

Table 5. Height, diameter, and tillers number, of pre-sprouted seedlings, cultivar IACSP95-5000, at 60 and 90 DAP. Piracicaba, SP, Brazil, 2017/18.

\begin{tabular}{|c|c|c|c|c|c|c|c|c|}
\hline \multirow{2}{*}{ Treatments } & \multirow{2}{*}{ Rates $^{1}$} & \multirow{2}{*}{ Time $^{2}$} & \multicolumn{2}{|c|}{ Height $(\mathrm{cm})$} & \multicolumn{2}{|c|}{ Diameter $(\mathrm{mm})$} & \multicolumn{2}{|c|}{ Tillers } \\
\hline & & & 60 & 90 & 60 & 90 & 60 & 90 \\
\hline control with weeding & - & - & $34.1^{b}$ & $54.0^{a}$ & $18.0^{\mathrm{a}}$ & $21.8^{a}$ & $10.7^{a}$ & $14.4^{\mathrm{a}}$ \\
\hline control without weeding & - & - & $55.1^{a}$ & $72.0^{\mathrm{a}}$ & $18.2^{\mathrm{a}}$ & $23.3^{a}$ & $2.0^{\mathrm{b}}$ & $1.7^{\mathrm{b}}$ \\
\hline sulfentrazone & 800 & PRE & $31.7^{b}$ & $52.9^{a}$ & $14.4^{\mathrm{a}}$ & $20.0^{a}$ & $5.0^{\mathrm{b}}$ & $4.4^{b}$ \\
\hline diclosulam & 193.17 & PRE & $14.5^{c}$ & $23.8^{\mathrm{b}}$ & $5.4^{b}$ & $11.7^{\mathrm{b}}$ & $0.1^{\mathrm{c}}$ & $0.4^{\mathrm{c}}$ \\
\hline imazapic & 133 & PRE & $14.2^{\mathrm{c}}$ & $33.3^{b}$ & $6.0^{\mathrm{b}}$ & $14.1^{\mathrm{b}}$ & $0.2^{c}$ & $0.3^{c}$ \\
\hline imazapyr & 500 & PRE & $4.2^{\mathrm{d}}$ & $2.7^{c}$ & $3.8^{b}$ & $2.7^{c}$ & $0.0^{c}$ & $0.0^{c}$ \\
\hline halosulfuron & 112.5 & POST & $52.1^{\mathrm{a}}$ & $63.1^{\mathrm{a}}$ & $17.4^{\mathrm{a}}$ & $22.5^{a}$ & $2.2^{\mathrm{b}}$ & $2.4^{b}$ \\
\hline ethoxysulfuron & 135 & POST & $52.7^{a}$ & $55.9^{a}$ & $18.0^{\mathrm{a}}$ & $21.6^{a}$ & $3.0^{b}$ & $2.4^{b}$ \\
\hline MSMA & 1,975 & POST & $53.2^{a}$ & $61.0^{a}$ & $17.7^{\mathrm{a}}$ & $20.9^{a}$ & $2.6^{\mathrm{b}}$ & $2.2^{\mathrm{b}}$ \\
\hline \multirow[t]{4}{*}{$2,4-D$} & 1,340 & POST & $50.8^{a}$ & $57.9^{a}$ & $16.0^{\mathrm{a}}$ & $21.0^{\mathrm{a}}$ & $2.5^{\mathrm{b}}$ & $2.0^{\mathrm{b}}$ \\
\hline & & Mean & 36.2 & 47.7 & 13.5 & 18.0 & 2.8 & 3.0 \\
\hline & & CV (\%) & 14.1 & 17.0 & 15.6 & 12.7 & 17.9 & 15.8 \\
\hline & & $\mathrm{F}$ & $*$ & $*$ & $*$ & $*$ & $*$ & $*$ \\
\hline
\end{tabular}

DAP: days after planting; ${ }^{2}$ Herbicide application time: PRE-planting (one day before planting) and POST-planting (30 DAP). ${ }^{*}$ Means followed by the same letter in the column do not differ by the Scott-Knott test $(p<0.05)$. 
For the evaluation at 120 DAP, the analysis of variance indicated statistical difference for all variables. The lowest heights were observed for the application of diclosulam $(37.1 \mathrm{~cm})$, imazapic $(45.3 \mathrm{~cm})$, and imazapyr $(10.75 \mathrm{~cm})$, and for ethoxysulfuron which differed from control (with weeding). For diameter, the lowest values were also obtained for diclosulam, imazapic, and imazapyr (13.0, 16.3, and $4.8 \mathrm{~mm}$ ). All treatments reduced the number of tillers when compared to control (with weeding). At 240 DAP, the analysis of variance showed a reduction in height for all treatments compared to weeding control, except for the herbicide sulfentrazone, which was the same. The diameter was lower only for imazapyr application, as there were no more plants to be evaluated due to plant death. All treatments were lower than control (with weeding) in the number of tillers and weight of ten stems, except sulfentrazone herbicide for weight variable (Table 6).

Table 6. Height, diameter, and tillers number, at 120 and $240 \mathrm{DAP}$, and yield of pre-sprouted seedlings, cultivar IACSP95-5000. Piracicaba, SP, Brazil, 2017/18.

\begin{tabular}{|c|c|c|c|c|c|c|c|c|c|}
\hline \multirow{2}{*}{ Treatments } & \multirow{2}{*}{ Rates $^{1}$} & \multirow{2}{*}{ Time $^{2}$} & \multicolumn{2}{|c|}{ Height (cm) } & \multicolumn{2}{|c|}{ Diameter $(\mathrm{mm})$} & \multicolumn{2}{|c|}{ Tillers } & \multirow{2}{*}{$\begin{array}{l}\text { Yield } \\
\left(\mathrm{t} \mathrm{ha}^{-1}\right)\end{array}$} \\
\hline & & & 120 & 240 & 120 & 240 & 120 & 240 & \\
\hline control with weeding & - & - & $102.4^{\mathrm{a}}$ & $143.0^{\mathrm{a}}$ & $28.6^{a}$ & $33.3^{a}$ & $12.8^{a}$ & $80.0^{\mathrm{a}}$ & $66.2^{a}$ \\
\hline control without weeding & - & - & $92.7^{\mathrm{a}}$ & $97.3^{\mathrm{b}}$ & $26.6^{a}$ & $31.6^{a}$ & $2.5^{\mathrm{c}}$ & $23.5^{b}$ & $11.0^{c}$ \\
\hline sulfentrazone & 800 & PRE & $84.7^{a}$ & $111.5^{b}$ & $26.2^{\mathrm{a}}$ & $32.2^{\mathrm{a}}$ & $5.9^{b}$ & $36.0^{\mathrm{b}}$ & $27.1^{\mathrm{b}}$ \\
\hline diclosulam & 193.17 & PRE & $37.1^{\mathrm{b}}$ & $44.9^{c}$ & $13.0^{b}$ & $23.3^{b}$ & $0.7^{d}$ & $16.3^{c}$ & $2.9^{c}$ \\
\hline imazapic & 133 & PRE & $45.3^{b}$ & $52.2^{c}$ & $16.3^{b}$ & $25.1^{b}$ & $2.8^{c}$ & $22.3^{b}$ & $6.4^{c}$ \\
\hline imazapyr & 500 & PRE & $10.8^{c}$ & $0.0^{d}$ & $4.8^{c}$ & $0.0^{c}$ & $0.3^{d}$ & $0.0^{c}$ & $0.0^{c}$ \\
\hline halosulfuron & 112.5 & POST & $89.7^{a}$ & $104.5^{b}$ & $25.8^{\mathrm{a}}$ & $32.3^{a}$ & $4.9^{b}$ & $30.0^{b}$ & $18.4^{\mathrm{b}}$ \\
\hline ethoxysulfuron & 135 & POST & $74.7^{a}$ & $89.8^{b}$ & $23.9^{a}$ & $31.1^{\mathrm{a}}$ & $5.3^{b}$ & $33.0^{b}$ & $16.8^{\mathrm{b}}$ \\
\hline MSMA & 1,975 & POST & $87.2^{\mathrm{a}}$ & $99.6^{b}$ & $25.1^{\mathrm{a}}$ & $31.5^{\mathrm{a}}$ & $5.3^{b}$ & $35.0^{b}$ & $19.8^{b}$ \\
\hline \multirow[t]{4}{*}{$2,4-D$} & 1,340 & POST & $91.2^{\mathrm{a}}$ & $95.1^{b}$ & $24.7^{\mathrm{a}}$ & $33.4^{\mathrm{a}}$ & $4.6^{b}$ & $34.0^{\mathrm{b}}$ & $18.9^{\mathrm{b}}$ \\
\hline & & Mean & 71.5 & 83.8 & 21.4 & 27.4 & 4.5 & 31.0 & 18.8 \\
\hline & & CV (\%) & 14.2 & 17.9 & 12.4 & 15.4 & 35.9 & 38.9 & 45.0 \\
\hline & & $\mathrm{F}$ & $*$ & $*$ & $*$ & $*$ & $*$ & $*$ & $*$ \\
\hline
\end{tabular}

DAP: days after planting; ${ }^{2}$ Herbicide application time: PRE-planting (one day before planting) and POST-planting (30 DAP).* Means followed by the same letter in the column do not differ by the Scott-Knott test $(p<0.05)$.

\section{Discussion}

The lower number of tillers combined with the smaller weight of ten stems is reflected at yield. However, it is noteworthy that the low yields are also due to the experiment time ( 240 days) because the aim of the study is to simulate a seedling vivarium, in which the recommendation is 8 to 10 months (Amaral and Azania 2017). For the application of sulfentrazone, halosulfuron, ethoxysulfuron, MSMA, and 2,4-D, the yield was lower than that observed in the weeding control, but all were superior to the control (without weeding). These results suggest that the reduction in yield is due to insufficient weed control, not due to lack of selectivity, which is also indicated by the absence of severe sugarcane injury symptoms. While for the application of diclosulam, imazapic, and imazapyr there was lower yield even than the control (without weeding), suggesting that these herbicides were not selective for sugarcane (Table 6). The high symptoms of injury in PSS in PRE applications were evidenced, possibly due to the time elapsed between herbicide application and planting, which was one day. Diclosulam is recommended for weed pre-emergence, in conventional planting, after planting or harvest of sugarcane, at a rate of 105.8 to $194 \mathrm{~g} \mathrm{a.i.} \mathrm{ha-1,} \mathrm{for} \mathrm{the}$ control mainly of U. plantaginea, D. horizontalis, I. triloba L. and C. rotundus (Rodrigues and Almeida 2018). However, there is no recommendation for planting with PSS.

It is noteworthy that the three herbicides applied in PRE (diclosulam, imazapic, and imazapyr), that were potentially non-selective, are of the same mechanism of action (ALS inhibitors), which suggests care in the application of herbicides of this mechanism one day before the planting of PSSs. The selectivity of herbicides may be different in the PSS system than that observed in the conventional system, the PSSs already have a root system, and when placed in contact with the soil the root system is in the region treated with the herbicide, which is the main route of absorption of herbicides applied at PRE, and there may be an 
absence of selectivity by positioning. Possibly higher rates of absorption and translocation of herbicides (Dias et al. 2017; Silva et al. 2018).

Planting PSS from CTC 14, CTC 7 and RB966928 cultivars, shortly after diclosulam application (200 g a.i. ha ${ }^{-1}$ ), resulted in injury of $8.3 \%$ (14 DAA), 21.9\% (28 DAA), 34.6\% (42 DAA) e 26.3\% (63 DAA). At 63 DAA, the plants had not yet recovered from injuries, with symptoms of $33.5 \%$ (CTC 14), $21 \%$ (CTC 7) and $24.3 \%$ (RB966928). Consequently, there was a reduction in plant height in relation to control (without weeding) and a lower number of tillers in cultivars CTC 14 and RB966928 (Dias et al., 2017). Reduction in height and number of tillers was also observed in the present study for the cultivar IACSP95-5000, with higher symptoms of injury: 46.25\% (15 DAP), 51.25\% (30 DAP), $58.75 \%$ (45 DAP) and 48.75\% (60 DAP).

PRE application of diclosulam at rates 126 or $168 \mathrm{~g}$ a.i. ha ${ }^{-1}$ resulted in excellent (over 95\%) weed control for U. plantaginea, U. decumbens, P. maximum, and D. horizontalis (Takano et al. 2017). For $C$. rotundus, the use of diclosulam (200 $\mathrm{g}_{\text {a.i. }} \mathrm{ha}^{-1}$ ) reached control scores of $91.5 \%$ (45 DAA), 96.5\% (60 DAA) and $93.5 \%$ (90 DAA), reducing the number of germinated, dormant and dead tubers in relation to control (without application) (Martins et al. 2009). In the present study, diclosulam provided a reduction in the emergence of $C$. rotundus, $P$. maximum and $D$. ciliaris species reaching overall control of $82.67 \%$ (15 DAP), 92.5\% (30 DAP), 80\% (45 DAP ), reducing from $60 \mathrm{DAP}$, mainly due to the presence of species such as $A$. tenella and $P$. oleraceae.

The use of imazapic (140 g a.i. ha ${ }^{-1}$ ) in pre-emergence of cultivar SP81-3250 (Plene ${ }^{\circledast}$ system) caused severe injury, which reflected in high harvest losses. The herbicide also reduced plant height by $33.6 \mathrm{~cm}$, the number of tillers by 13 , the leaf + stem dry mass by $40.1 \mathrm{~g}$ and the root dry mass by $96.9 \mathrm{~g}$, all compared to the control (without application), 110 days after budding (Bertolino and Alves 2014). In the present work, the use of imazapic (133 g a.i. ha ${ }^{-1}$ ) in PSS reduced plant height by $90.8 \mathrm{~cm}$, the number of tillers by 57.57 , the weight of ten stalks by $5.05 \mathrm{~g}$ and the yield on $59.81 \mathrm{t} \mathrm{ha}^{-1}$, all compared to control (with weeding) at 240 DAP.

In sugarcane, imazapic is recommended at a rate of $245 \mathrm{~g}$ a.i. ha ${ }^{-1}$, at 30 to 45 days before planting, at pre or post-emergence of weeds. In new cycles, after the first harvest, until $122,5 \mathrm{~g}$ a.i. ha- ${ }^{-1}$, with the application before crop emergence. This herbicide acts in the control of several weeds that were present in the study area as $A$. tenella, E. indica, $P$. oleraceae, $P$. maximum, and $U$. plantaginea. Thus, as in $C$. rotundus control at $133 \mathrm{~g}$ a.i. ha-1 (medium soil) and $145 \mathrm{~g}^{-1}$ a.i. ha ${ }^{-1}$ (clay soil) (Rodrigues and Almeida 2018). For imazapic, general weed control was considered "very good" (81 - 90\%) until 30 DAP, "good" (71 - 80\%) at 45 DAP, and "sufficient" (61-70\%) at 60 DAP. For C. rotundus, the herbicide probably acted by preventing plant germination or emergence. The effective control of imazapic over this weed has been proven by several authors. Simoni et al. (2006) observed a reduction in the dry mass of the shoot and basal bulbs at rate $147 \mathrm{~g}$ a.i. ha-1.

For sulfentrazone, 37.5\% (30 DAP) and 20\% (45 DAP) injury symptoms were observed, characterized as red spots on the leaves, which were no longer seen from 60 DAP. Martins et al. (2009) found red elliptic stains on the leaf. The injury was also found by Sabbag et al. (2017) at PSS of RB867515, RB855156, RB966928, and RB975201, for sulfentrazone (700 g a.i. ha- ${ }^{-1}$ ), at 3 and 10 DAP. The rate of $800 \mathrm{~g}^{2}$.i. ha-1 of sulfentrazone, applied on the same day of planting provided high injury, and the different cultivars were tolerant up to $400 \mathrm{~g}$ a.i. ha-1 (Silva et al. 2019).

The selectivity of sulfentrazone ( $800 \mathrm{~g}$ ai ha ${ }^{-1}$ ) in PSS was observed by Perez (2017), who found injury of $21.3 \%$ (15 DAA), 20\% (30 DAA), 16.3\% (60 DAA), 11.3\% (90 DAA) and 5\% (120 DAA) when the herbicide was applied one day before planting of CTC 11 cultivar. However, it was considered selective because it did not reduce plant height, number of tillers, and yield. In the cultivar of the present study, no injuries were observed from 60 DAP. The decrease in yield and the number of tillers can be attributed to the level of weed control, which was "good" (71-80\%) only until 45 DAP, with new weed germination and emergence, which started to compete with the crop and consequently reducing the yield.

In the present study, the herbicide was effective up to 45 DAP, from 60 DAP the control reduced to 90 DAP, probably due to the high seed bank infestation, mainly of monocotyledons such as $C$. rotundus, $D$. ciliaris, P. maximum and C. echinatus, besides eudicotyledons $A$. tenella and $P$. oleraceae. The efficacy of sulfentrazone is proven for several weeds, such as E. heterophylla, I. nil (L.) Roth, I. hederifolia, I. quamoclit, I. triloba and M. aegyptia (L.) Urb. (Azania et al. 2009), C. rotundus (Simoni et al. 2006; Almubarak and 
Srivastava 2015). Amstalden et al. (2008) analyzed the use of sulfentrazone (800 g a.i. ha-1) in 100 sugarcane crops in the control of $C$. rotundus, in which control over $80 \%$ was observed in 88 crops. In the remaining 12 , where the control was less than $80 \%$, the results are explained by the high infestations (some with more than 500 plants $\mathrm{m}^{-2}$ ) or using lower rates than recommended.

The efficacy of sulfentrazone up to 45 DAP can also be explained by the cumulative rainfall of 338.6 $\mathrm{mm}$ until this assessment. Absorption of this herbicide is performed mainly via the root. High temperatures and rainfall may have contributed to the herbicide being leached into deeper soil layers, where most of the weed seed bank is not concentrated, allowing a new emergence flow before the crop could close the rows. As highlighted by Carbonari et al. (2016), this herbicide is recommended especially in the dry season, $20 \mathrm{~mm}$ of precipitation is already enough to extract about $80 \%$ of the herbicide applied under the straw and sugarcane residues. Monquero et al. (2010) observed that the effect of leaching increased as rainfall increased. Regarding the persistence of sulfentrazone ( $800 \mathrm{~g}$ a.i. ha- ${ }^{-1}$ ), they found that up to 45 DAA the accumulated precipitation was $174 \mathrm{~mm}$, which contributes to an $80 \%$ control of the bioindicator.

For imazapyr, it was verified that the application one day before planting leads to the death of the IACSP95-5000 cultivar. This result was already expected since the herbicide is recommended in pre or postemergence of weeds and should wait at least 60 days for planting (Rodrigues and Almeida 2018). Regarding weed control, imazapyr was the one that kept control as "sufficient" for the longest time (61 - 70\%), with reduction only at 90 DAP (57.5\%). Imazapyr has a broad control spectrum, encompassing the main weeds present in the study area: $C$. rotundus, $A$. tenella, B. subalternans, $U$. plantaginea, $C$. benghalensis, E. indica, and P. maximum. Dias et al. (2005) observed $100 \%$ control for D. ciliaris at 21 DAA of imazapyr (125 g a.e. ha ${ }^{-1}$ ).

No injury was observed when post-planting herbicides were used. Chand et al. (2014) found no injury to halosulfuron (up to $150 \mathrm{~g}$ a.i. $\mathrm{ha}^{-1}$ ) in sugarcane for application at $45 \mathrm{DAP}$. The high weed infestation in post-planting treatments made the plants compete for light. This fact can be observed by the higher heights in these treatments and in the control (without weeding) at $60 \mathrm{DAP}$, besides the smaller amount of tillers. Being a C4 metabolism plant, sugar cane needs a lot of light; reduced irradiation conditions lead to longer, thin stalks, and lower tillering plants (Rodrigues 1995). Thus, sugarcane tillering will be lower under low light intensity conditions (Jadoski et al. 2010).

Chand et al. (2014) found control of elevated C. rotundus, above $90 \%$ at 60 DAA, when halosulfuron (45 DAP) was used at 60,67.5, 75, and $150 \mathrm{~g}$ a.i. ha-1. In contrast, mechanical weeding and continuous chemical management with atrazine $\left(2,000 \mathrm{~g}\right.$ a.i. ha $\left.{ }^{-1}\right)$ at pre-emergence, and 2,4-D $\left(1,000 \mathrm{~g}\right.$ a.e. ha ${ }^{-1}$, at 45 $\mathrm{DAP}$ ) increased the number of plants $\mathrm{m}^{-2}$, since they were not effective in controlling this species. However, atrazine and 2,4-D were effective in controlling other monocotyledons and eudicotyledons, while halosulfuron did not provide large reductions in dry mass of these species. In the present study, it was found that halosulfuron alone was not enough to keep sugarcane free from weeds, mainly grass species, which consequently reduced crop yield.

\section{Conclusions}

Sugarcane weed management through chemical control is an important tool that helps maintain yield. However, it should be combined with other methods, prioritizing integrated weed management, especially when species are difficult to control. Pre-planting herbicides provided the best weed controls, but diclosulam, imazapic, and imazapyr caused a severe injury in PSS. The sulfentrazone gave the second highest yield, after control (with weeding). Nevertheless, sulfentrazone was considered the most satisfactory in this study. Post-planting herbicides did not cause injury to the sugarcane but alone were not effective in controlling weeds, which caused a reduction in yield. The results obtained here are noteworthy since there are few studies on herbicide management at the field in the sugarcane PSS system.

Authors' Contributions: GIRALDELI, A.L.: conception and design, acquisition of data, analysis and interpretation of data, drafting the article, and critical review of important intellectual content; SILVA, A.F.M.: conception and design, acquisition of data, analysis and interpretation of data, drafting the article, and critical review of important intellectual content; BACCIN, L.C.: conception and design, acquisition of data, analysis and interpretation of data, drafting the article, and critical review of important intellectual content; ARAÚJO, L.S.: conception and design, acquisition of data, analysis and interpretation of data, drafting the article, and critical review of important intellectual content; SILVA, G.S.: conception and design, acquisition of data, analysis and interpretation of data, drafting the article, and critical review of important intellectual content; 
PAGENOTTO, A.C.V.: conception and design, acquisition of data, analysis and interpretation of data, drafting the article, and critical review of important intellectual content; VICTORIA FILHO, R.: conception and design, acquisition of data, analysis and interpretation of data, drafting the article, and critical review of important intellectual content. All authors have read and approved the final version of the manuscript.

Conflicts of Interest: The authors declare no conflicts of interest.

Ethics Approval: Not applicable.

Acknowledgments: The authors would like to thank the funding for the realization of this study provided by the Brazilian agency CAPES (Coordenação de Aperfeiçoamento de Pessoal de Nível Superior - Brasil), Finance Code 001.

\section{References}

ALMUBARAK, N.F. and SRIVASTAVA, T.K. Effect of weed control methods on growth and development of weeds in sugarcane (Saccharum officinarum L.) fields. International Journal Applied Agricultural Sciences. 2015, 1(3), 49-54. https://doi.org/10.11648/j.ijaas.20150103.11

ALVES, M., et al. Diversity of cyperaceae in Brazil. Rodriguésia. 2009, 60(4), 771-782. http://dx.doi.org/10.1590/2175-7860200960405

AMARAL, F.C.R. and AZANIA, C.A.M. Períodos de interferência de plantas daninhas em MPBs. Canavieiros. 2017, 127(jan), 46-47.

AMSTALDEN, F., BRUSANTIN, L.V., DIAS, A.C.R. and CHRISTOFFOLETI, P.J. Manejo químico de Cyperus rotundus e Digitaria spp. em áreas comerciais de produção de cana-de-açúcar. Nucleus. 2008, 5(2) 102-110. http://dx.doi.org/10.3738/nucleus.v5i2.109

AZANIA, C.A.M., et al. Chemical management of convolvulaceae and euphorbiaceae in sugarcane during dry season. Planta Daninha. 2009, 27(4), 841-848. http://dx.doi.org/10.1590/S0100-83582009000400023

BERTOLINO, C.B. and ALVES, P.L.C.A. Selectivity of herbicides for sugarcane Plene system in pre and post-emergence. Revista Brasileira de Herbicidas. 2014, 13(3), 197-206. https://doi.org/10.7824/rbh.v13i3.249

BRECKE, B.J., STEPHENSON, D.O. and UNRUH, J.B. Control of purple nutsedge (Cyperus rotundus) with herbicides and mowing. Weed Technology. 2005, 19(4), 809-814. https://doi.org/10.1614/WT-04-254R1.1

CARBONARI, C.A., et al. Dynamics of sulfentrazone applied to sugarcane crop residues. Weed Science. 2016, 64(1), 201-206. https://doi.org/10.1614/WS-D-14-00171.1

CHAND, M., SINGH, S., BIR, D., SINGH, N. and KUMAR, V. Halosulfuron methyl: a new post emergence herbicide in India for effective control of Cyperus rotundus in sugarcane and its residual effects on the succeeding crops. Sugar Tech. 2014, 16(1), 67-74.

https://doi.org/10.1007/s12355-013-0263-4

DIAS, J.L.C.S., SILVA JÚNIOR, A.C.D., QUEIROZ, J.R.G. and MARTINS, D. Herbicides selectivity in pre-budded seedlings of sugarcane. Arquivos do Instituto Biológico. 2017, 84, e0112015. http://dx.doi.org/10.1590/1808-1657000112015

DIAS, N.M.P., et al. Population dynamics of Digitaria spp submitted to selection pressure by herbicides in sugarcane crop. Journal of Environmental Science and Health, Part B. 2005, 40(1), 21-28. https://doi.org/10.1081/PFC-200034200

DURIGAN, J.C., TIMOSSI, P.C. and CORREIA, N.M. Effects of purple nutsedge plant densities and chemical control on sugarcane yield. Planta Daninha. 2005, 23(3), 463-469. https://doi.org/10.1590/s0100-83582005000300010

EUROPEAN WEED RESEARCH COUNCIL [EWRC]. Report of the third and fourth meetings of the European Weed Research Council Committee on methods. Weed Research. 1964, 4(1), 79. https://doi.org/10.1111/j.1365-3180.1964.tb00271.x

FERREIRA, A., et al. Geographical distribution of the weeds seed bank of under different managements of sugar cane in Rio Brilhante, State of Mato Groso do Sul, Brazil. Bioscience Journal. 2013, 29(Supplement 1), 1458-1468.

FERREIRA, D.F. Sisvar: a computer statistical analysis system. Ciência e Agrotecnologia. 2011, 35(6), 1039-1042.

http://dx.doi.org/10.1590/s1413-70542011000600001

FERREIRA, E.A., et al. Weed management in raw sugarcane. Planta Daninha. 2010, 28(4), 915-925. http://dx.doi.org/10.1590/S010083582010000400025

GIRALDELI, A.L., et al. Initial interference of Cyperus rotundus L. in pre-sprouted seedlings of sugarcane cultivars RB985476 and IACSP95-5000. Agronomia Colombiana. 2018, 36(3), 210-216. http://dx.doi.org/10.15446/agron.colomb.v36n3.73317

JADOSKI, C.J., et al. Physiology development in the vegetative stage of sugarcane. Applied Research \& Agrotechnology. 2010, 3(2), 169-186. https://doi.org/10.5777/paet.v3i2.1064

KUVA, M.A., PITELLI, R.A., SALGADO, T.P. and ALVES, P.L.C.A. Phytosociology of weed community in no-burn sugar cane agroecosystems. Planta Daninha. 2007, 25(3), 501-511. http://dx.doi.org/10.1590/S0100-83582007000300009

LORENZI, H. Manual de identificação e controle de plantas daninhas: plantio direto e convencional. 7ed. Nova Odessa: Instituto Plantarum, 2014.

MARTINS, D., TOMAZELA, M.S., DAVID, D.V. and MARTINS, C.C. Purple nutsedge control with sulfentrazone and diclosulam and tubers viability in different soil depths. Bragantia. 2009, 68(2), 357-366. http://dx.doi.org/10.1590/\$0006-87052009000200009 
MONQUERO, P.A., et al. Leaching and persistence of sulfentrazone and imazapic. Planta Daninha. 2010, 28(1), 185-195. http://dx.doi.org/10.1590/S0100-83582010000100022

MUELLER-DOMBOIS, D. and ELLENBERG, H. Aims and methods of vegetation ecology. New York: Wiley, 1974.

PEREZ, L.L. Seletividade de sulfentrazone e clomazone aplicados em pré-plantio de mudas pré-brotadas de cana-de-açúcar CTC 11 [dissertação]. Piracicaba: Universidade de São Paulo, Escola Superior de Agricultura "Luiz de Queiroz", 2017.

PIMENTEL-GOMES, F. and GARCIA, C.H. Estatística aplicada a experimentos agronômicos e florestais: exposição com exemplos e orientações para uso de aplicativos. Piracicaba: FEALQ, 2002.

RODRIGUES, B.N. and ALMEIDA, F.S. Guia de herbicidas. 7.ed. Londrina: Ed. authors, 2018.

RODRIGUES, J.D. Fisiologia da cana-de-açúcar. Botucatu: Universidade Estadual Paulista "Júlio de Mesquita Filho", Instituto de Biociências, 1995.

SABBAG, R.S., MONQUERO, P.A., HIRATA, A.C.S. and SANTOS, P.H.V. Crescimento inicial de mudas pré brotadas de cana-de-açúcar submetidas a aplicação de herbicidas. Revista Brasileira de Herbicidas. 2017, 16(1), 38-49. https://doi.org/10.7824/rbh.v16i1.481

SILVA, B.P., ALMEIDA, R.O., SALGADO, T.P. and ALVES, P.L.C.A. Efficacy of imazapic, halosulfuron and sulfentrazone for Cyperus rotundus L. control in response to weed tuber density. African Journal of Agricultural Research. 2014, 9(47), 3458-3464.

https://doi.org/10.5897/AJAR2013.8411

SILVA, G.S., et al. Seletividade de sulfentrazone aplicado em pré-plantio incorporado e em pré-emergência da cultura da cana-de-açúcar. Colloquium Agrariae. 2019, 15(1), 85-94. http://dx.doi.org/10.5747/ca.2019.v15.n1.a273

SILVA, G.S., et al. Manejo de plantas daninhas no sistema de mudas pré-brotadas de cana-de-açúcar. Revista Brasileira de Herbicidas. 2018, 17(1), 86-94. https://doi.org/10.7824/rbh.v17i1.526

SIMONI, F., et al. Efficacy of imazapic and sulfentrazone applied on Cyperus rotundus under different rain and sugarcane straw conditions. Planta Daninha. 2006, 24(4), 769-778. http://dx.doi.org/10.1590/S0100-83582006000400018

TAKANO, H.K., et al. Dry season and soil texture affect the chemical control of monocotyledonous in sugarcane. Comunicata Scientiae. 2017, 8(3), 477-485. https://doi.org/10.14295/cs.v8i3.1594

VELINI, D.E., OSIPE, R. and GAZZIERO, D.L.P. Procedimentos para instalação, avaliação e análise de experimentos com herbicidas. Londrina: SBCPD, 1995.

Received: 31 November 2019 | Accepted: 25 August 2020 | Published: 13 October 2021

This is an Open Access article distributed under the terms of the Creative Commons Attribution License, which permits unrestricted use, distribution, and reproduction in any medium, provided the original work is properly cited. 